\title{
Exchange Rate Pass-through and Monetary Policy in Transition Economy: Evidence from Tunisia with a Disaggregated VAR Analysis*
}

\author{
Ahlem Dahem $^{1}$ and Fatma Siala Guermazi ${ }^{2}$
}

\begin{abstract}
:
Relying on monthly and quarterly data, from 2000 to 2015, this paper keeps up with SVAR modeling and price chain study, through a disaggregate approach that aims at analyzing the exchange rate pass-through (ERPT) on the various components of consumer price index $(C P I)$.
\end{abstract}

To our knowledge, this study is the first attempt at ERPT estimation through a disaggregate approach for the CPI. The results show that the total ERPT is about $20 \%$. Specifically, $10 \%$ of PT on the administered prices after 2011 revolution date (6\% of PT for food administered prices and $7 \%$ of PT for energy prices), which contradicts the prevailing theory that admits the inexistence of PT for administered prices.

Our findings confirm the importance of a disaggregate analysis for studying ERPT to contain inflation.

Keywords: Exchange Rate Pass-through - Monetary policy - Emerging Market Disaggregated analysis

JEL Classification: C32, E31, E42, E52, F31, F41, O55

\footnotetext{
* We would like to thank "La Direction de la Stratégie de la Politique Monétaire de la Banque Centrale de Tunisie" to its head Mr Mohamed Salah Souilem and in particular its collaborators: Mrs Rym Kolsi, Mr Moez Lajmi and Mrs Sihem Khadhraoui for their suggestions, comments and support.

${ }^{1}$ Laboratoire d'Integration Economique Internationale (LIEI), Université de Tunis El Manar - Campus Universitaire Farhat Hached Tunis B.P. $n^{\circ} 94$ - ROMMANA 1068, Tunisie. Email: ahlem.daham@gmail.com

${ }^{2}$ Laboratoire d'Integration Economique Internationale (LIEI), Université de Tunis El Manar - Campus Universitaire Farhat Hached Tunis B.P. $n^{\circ} 94$ - ROMMANA 1068, Tunisie. Email: fatmasialag@gmail.com
} 


\section{Introduction}

The issue of studying the impact of exchange rate's variations on prices (passthrough) had caught, a longtime ago, the attention not only of the literature but also of central banks. The implications of this issue on international economics had certainly reemerged in the 2000s Goldfajn \& Werlang (2000), Taylor (2000), Haussmann (2001), Devereux and al (2001, 2002), Choudhri \& Hakura (2001), Bailliu et al (2004), Gagnon \& Ihrig (2004), Campa \& Goldberg (2006), Barhoumi and al (2006, 2008), Ito \& Sato (2006), Miguel and Reginaldo (2010), Delatte \& Villavicencio (2012).

Relevant research has shown that prices 'responsiveness to currency fluctuations is quiet high in emerging countries, creating thus a high degree of pass-through. The shocks on exchange rate in these countries are in general large and persistent which can impede the different policies of central banks. This latter effect can threaten their credibility (inflation targeting as monetary policy).

In fact, this issue has pushed economists into determining the deciding microeconomic and macroeconomic factors can explain exchange rate pass-through. Many theories have been sought to account for the transmission of exchange rates, such as: degree of economic openness, market segmentation, inflationary environment (Taylor 2000), Pricing to Market (PTM), markup's phenomenon, and importations composition (Campa \& Goldberg, 2006). Since then, different concepts of the pass-through phenomenon had been put forward, distinguishing between: complete and incomplete pass-through, bearing on the main definition of passthrough: transmission to import prices (Goldberg \& Knetter, 1997).

Therefore, this pass-through phenomenon has evolved to enclose domestic prices (Haussman 2001; Bailliu \& Fuji 2004). Then, the concepts of the direct effect (tradable pass-through: on PPI) and the indirect effect (non-tradable pass-through: on CPI) of exchange rate pass-through were proposed (Edwards, 2006; Siala et al., 2012). Therefore, the asymmetry of exchange rate pass-through: pointed to the difference between the impacts of appreciating and depreciating exchange rate (Delatte \& Villavicencio, 2012; El Bejaoui, 2013; Miller and Choi, 2014; Thalassinos and Pociovalisteanu, 2007; Thalassinos et al., 2015).

Accordingly, the issue of pass-through remains relevantly debated by the recent literature and needs an update for a better conduct of monetary policy. On the academic level, some empiric studies explained that the relationship between inflation and exchange rate by a simple regression equation (Campa et al. 2005, 2006). In certain cases, many authors such as McCarthy (1999, 2000, and 2007), Thalassinos and Politis (2012), Ito and Sato (2006), used the VAR approach to examine the transmission of several shocks to exchange rate on inflation. Moreover, the panel data method had been used in many studies such as those of Mihaljck \& Klau (2001), Darvas (2001), and recently Jimborean (2013). Nevertheless, 
researchers attempted to examine this issue in Tunisian context offer little results and the literature gave some restricted responses on the empirical levels. So, we aim in this paper to enrich the debate on «Monetary policy and exchange rate passthrough», in a small open economy in a transitional phase», particularly in Tunisia's case.

In this paper, essentially, we try to analyze the transmission of exchange rate before and after the revolution (2011), a comparison which is not treated before. It is necessary to specify that the problem remains always an important issue and needs an update to better understand countries in transitions, such as Tunisia. Specifically, we try to: understand the impact of exchange's rate variations on central bank's policies. On the other hand, in this paper, the data and methodology are not like previous research, which have only used global inflation and core inflation, yet our study contributes to this literature by testing the impact of exchange rate in Tunisia via a disaggregated analysis of exchange rate pass-through, by means of a defalcation of the consumer price index. However, to our knowledge, this study is the first to propose a disaggregated estimation of pass-through. It also provides a formal proof regarding the modeling approach, which is the favorite tool to analyze the transmission of the effect of exchange rate's variation's in Tunisia.

The study period stretches between 2000 and 2015 for monthly and quarterly data collected on Tunisia via SVAR modeling (structural VAR). The conclusions in this paper indicate that, first, the pass-through coefficient is more important for import prices (IMP) than for producer price index (PPI) and consumer price index (CPI). The whole coefficient of pass-through is about $10 \%$ before 2011 and $20 \%$ after 2011 for quarterly data. Second, there is an incomplete transmission on the two indices: IMP and PPI. These findings are widely validated by the literature. On the other hand, the main results of our pulsed shocks study show that there is a pass-through on administered prices about $10 \%$ after 2011 ; specifically, a degree of $6 \%$ for food administered prices and 7\% for energy prices after 2011 (for monthly data), unlike existing theory that admits an absence of a pass-through for administered prices. Our results confirm the importance of a disaggregated analysis of exchange rate passthrough, and provide decision makers with a view on the short and long run about inflation in Tunisia and help to adopt the appropriate strategies for the conduct of monetary policy to contain inflation.

The rest of the paper is structured as follows: Section 2 briefly summarizes monetary policy in Tunisia and the evolution of exchange rate, with an overview of passthrough in Tunisia. In section 3, we present the empiric methodology and the SVAR model. In section 4, we discuss the results. Finally, section 5 closes the paper.

\section{Monetary policy and exchange rate pass through in Tunisia}

According to the new monetary policy law of the $12^{\text {th }}$ of April 2016 in Tunisia, the main mission of the Central Bank of Tunisia: to preserve stability of prices and 
stability of the financial system ${ }^{3}$. However, the Central Bank of Tunisia (CBT) is moving in opposite directions: a discretionary monetary policy with multi-final goals: controlling inflation, preserving the financial system's stability, supporting economic activity, maintaining external equilibrium and competitiveness. For the exchange rate policy, Tunisia has moved from a de jure exchange rate regime "administered float" to a de facto exchange rate regime "Crawl-like arrangement" (according to the IMF's classification) ${ }^{4}$. For a better analysis of the exchange rate's transmission in the Tunisian economy, we should take in consideration its evolution.

\subsection{Evolution of the exchange rate in Tunisia}

During the 1990s, the monetary authorities in Tunisia, aiming to preserve competitiveness, have targeted the real effective exchange rate (REER) via the intervention by the CBT to adjust the nominal effective exchange (NEER) from time to time to compensate for the inflation gap compared to Tunisia's commercial partners. This period was characterized by prudent monetary and fiscal policies, with a stability of the international environment, which ensured a macroeconomic stability: a weak inflation rate around 3\%, a growth rate (GDP) of 5\% per year, while maintaining the equilibrium of the balance-of-payments.

However, since the 2000s, the Central Bank of Tunisia has implemented a flexible exchange rate policy and has fixed the money in a wider sense as a reliable nominal anchor. Domestic currency has depreciated since 2000 to support exportations. The total depreciation of the nominal effective exchange rate between 2000-2010 was around 30\% and between 2011-2015 it was around 15\% (inflation's increase between 2011-2015 was about 40\%). Some other reasons had contributed to this depreciation: the free trade agreement with the European Union - international competition - Dejerba's attack in 2002. Furthermore, during this period (2000-2010) the exchange rate regime for Tunisia was a "managed floating" one aiming at the equilibrium's path ${ }^{5}$. After January 2011, date of the Tunisian revolution, a flagrant depreciation of the dinar has been observed and Tunisia had to follow a more flexible exchange rate policy (impure floating) to preserve competitiveness and to avoid depleting exchange reserves.

\footnotetext{
${ }^{3}$ New law on monetary policy took place in Tunisia on the 12th of April 2016, which specifies the new status of the CBT, its main mission and objectives. See "projet de loi modifiant, loi 5890 version du 19 octobre 2015».

${ }^{4}$ IMF 2014 Annual Report FX regimes.

${ }^{5}$ Charfi \& Siala (2012) and Ben Ali \& Jardak (2014)
} 
Figure 1. Nominal and Real Effective Exchange Rate in Tunisia (1990-2015)

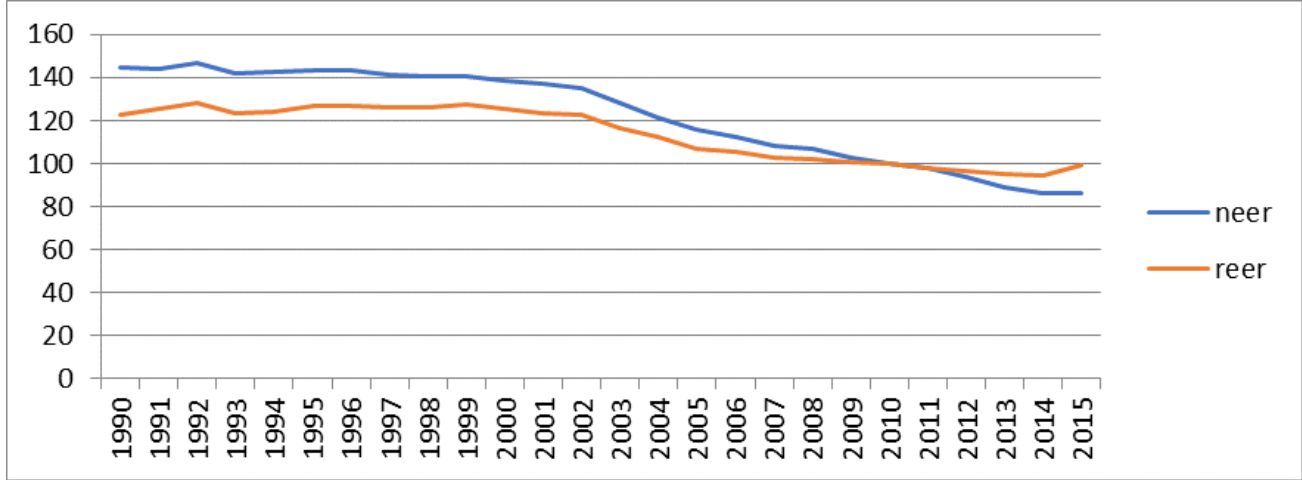

Source: authors

\subsection{Exchange Rate Pass-Through in Tunisia: Some empirical evidences}

The basic definition of exchange rate pass-through is of Glodberg \& Knetter's (1997). It identifies the transmission between exchange rate's variation and importation prices which are expressed by local currency; hence the concept of complete pass-through ${ }^{6}$. In fact, complete pass-through is not empirically valid (in particular for industrialized countries). In general, exchange rate pass-through is complete or almost complete only for a small opened economy with no important weight in international trade (Ben Ali \& Jardak, 2014). The issue of pass-through is extensively debated by the recent literature and always needs an update for a better conduct of monetary policy. Several studies were conducted in MENA countries and especially in Tunisian either to examine monetary policy in general or the transmission effect of the exchange rate. Table 1 below represents a summary of some empirical studies of exchange rate pass-through in Tunisia:

Table 1. Summary of the empirical studies of Exchange Rate Pass-through in Tunisia

\begin{tabular}{|l|l|l|l|}
\hline Study & Country-period & Model-variables & Results \\
\hline $\begin{array}{l}\text { Choudhri and Hakura } \\
\text { (2001) IMF }\end{array}$ & $\begin{array}{l}\text { 1979Q1-2000Q12 } \\
71 \text { countries including } \\
\text { Tunisia }\end{array}$ & $\begin{array}{l}\text { Time series, domestics and } \\
\text { foreign prices, exchange } \\
\text { rate (ER) }\end{array}$ & $\begin{array}{l}\text { Long term } \\
\text { (LT) ERPT } \\
\text { ERPT = 0,1 } \\
\text { H=20 }\end{array}$ \\
\hline Barhoumi (2006) & $\begin{array}{l}1980-2003 \\
12 \text { developing countries } \\
\text { including Tunisia }\end{array}$ & $\begin{array}{l}\text { non-stationary panel data } \\
\text { with Cointegration }\end{array}$ & $\begin{array}{l}\text { the LT } \\
\text { ERPT is } \\
\text { higher in } \\
\text { countries } \\
\text { with a fixed } \\
\text { exchange } \\
\text { rate and } \\
\text { low tariff } \\
\text { barriers }\end{array}$ \\
\hline
\end{tabular}

\footnotetext{
${ }^{6}$ The elasticity of import prices to change in exchange rates is unitary
} 


\begin{tabular}{|c|c|c|c|}
\hline $\begin{array}{l}\text { Sanhedji and al. (2007) } \\
\text { IMF }\end{array}$ & $\begin{array}{l}\text { Tunisia } \\
\text { From 1997M12-2006M12 }\end{array}$ & $\begin{array}{l}\text { Time series and panel data } \\
\text { (OLS and GMM) CPI, M4, } \\
\text { PPI, NEER }\end{array}$ & $\begin{array}{l}\text { ERPT is } \\
\text { about } 9-12 \\
\%\end{array}$ \\
\hline $\begin{array}{l}\text { Jebali S., Moulahi T. and } \\
\text { Mouha MS. (2009) }\end{array}$ & $\begin{array}{l}\text { Tunisia } \\
\text { From 1999M1 to } \\
\text { 2006M12 }\end{array}$ & $\begin{array}{l}\text { VAR } \\
\text { MMR, NEER, CPI and } \\
\text { PPI. }\end{array}$ & $\begin{array}{l}\text { a quick } \\
\text { reaction of } \\
\text { inflation }+ \\
\text { a low } \\
\text { degree of } \\
\text { ERPT }\end{array}$ \\
\hline Abida Z., Sghaier I. (2012) & $\begin{array}{l}\text { Tunisia and Morocco } \\
\text { From 1980Q1 to 2010Q4. }\end{array}$ & $\begin{array}{l}\text { SURE method } \\
\text { CPI, PPI, EUR/TND, } \\
\text { foreign prices (FP) }\end{array}$ & $\begin{array}{l}\text { *LT ERPT: } \\
\text { Tunisia } \\
0.238 \text { (for } \\
\text { CPI) }\end{array}$ \\
\hline $\begin{array}{l}\text { Charfi F. and Siala F. } \\
(2012)\end{array}$ & $\begin{array}{l}\text { Tunisia } \\
\text { From 1986M1 to } \\
\text { 2010M12. }\end{array}$ & $\begin{array}{l}\text { SURE method } \\
\text { CPI, PPI? EUR/TND, FP }\end{array}$ & $\begin{array}{l}\text { 1/ } 1986 \text { to } \\
\text { 2000: } \\
\text { LT ERPT: } \\
0,17(\mathrm{CPI}) \\
\text { 2/ } 2001 \text { to } \\
\text { 2010: } \\
\text { LT ERPT: } \\
0,086(\mathrm{CPI})\end{array}$ \\
\hline $\begin{array}{l}\text { Khemiri R. and Ben Ali } \\
\text { MS. (2013) }\end{array}$ & $\begin{array}{l}\text { Tunisia } \\
\text { from 2001M1 to 2009M12 }\end{array}$ & $\begin{array}{l}\text { FTP and TVTP methods } \\
\text { of Markov-switching } \\
\text { CPI, PPI, MMR, ER }\end{array}$ & $\begin{array}{l}\text { 1/ FTP : } \\
\text { ERPT : - } \\
0,132 \\
\text { 2/ TVTP } \\
\text { ERPT : } \\
-0,092\end{array}$ \\
\hline $\begin{array}{l}\text { Helali K., Kalai M. and } \\
\text { Boujelben T. (2014) }\end{array}$ & $\begin{array}{l}\text { Tunisia } \\
\text { from 1993M1 to 2011M6 }\end{array}$ & $\begin{array}{l}\text { SVAR + VECM } \\
\text { PPI, CPI, money supply, } \\
\text { REER, IMP }\end{array}$ & ERPT $13 \%$ \\
\hline $\begin{array}{l}\text { Ben Ali S. and Jardak T. } \\
\text { (2014) }\end{array}$ & $\begin{array}{l}\text { Tunisia } \\
\text { From 1994Q1-2010Q2 }\end{array}$ & $\begin{array}{llr}\text { Equation } & \text { with } & \text { time } \\
\text { variation: } & \text { state } & \text { space } \\
\text { model } & & \\
\text { CPI, NEER, FP, } & \\
\text { gap } & & \end{array}$ & $\begin{array}{l}\text { *short } \\
\text { term ERPT: } \\
15 \% \text { in } \\
1994-25 \% \\
\text { in } 2010 ; \\
* \\
\text { LT ERPT: } \\
38 \% \text { in } \\
1994-60 \% \\
\text { in } 2010\end{array}$ \\
\hline Guizani B. (2015) & $\begin{array}{ll}\text { Tunisia } & \\
\text { From } & \text { 2000M1 to } \\
2013 \mathrm{M} 12 & \end{array}$ & $\begin{array}{lr}\text { VECM } & \text { approach } \\
\text { Endogenous } & \text { variables: } \\
\text { GDP, CPI, } & \text { MMR, } \\
\text { EUR/TND } & \end{array}$ & $\begin{array}{l}\text { A quick } \\
\text { and high } \\
\text { pass- } \\
\text { through } \\
\text { after } 2011 \\
\text { in Tunisia } \\
\text { which } \\
\text { +increase } \\
\text { in inflation }\end{array}$ \\
\hline
\end{tabular}




\begin{tabular}{|l|l|l|l|}
\hline $\begin{array}{l}\text { The CBT study on the } \\
\text { mechanisms of } \\
\text { transmissions (2015) }\end{array}$ & $\begin{array}{l}\text { Tunisia } \\
\text { From 2000Q1 } \\
\text { To 2011Q3 }\end{array}$ & $\begin{array}{l}\text { VAR approach } \\
\text { The GDP excluding } \\
\text { agriculture, CPI excluding } \\
\text { fresh food and energy, } \\
\text { NEER }\end{array}$ & $\begin{array}{l}* \text { Short term } \\
: \\
\text { ERPT } \\
10 \%-15 \% \\
\text { for core } \\
\text { inflation } \\
\text { *Long } \\
\text { term : } \\
\text { ERPT } \\
\end{array}$ \\
& & $\begin{array}{l}20 \%-30 \% \\
\text { for core } \\
\text { inflation } \\
\text { and } \\
50 \%-70 \% \\
\text { for PPI }\end{array}$ \\
\hline
\end{tabular}

Source: authors

\section{Empirical Methodology}

\subsection{The SVAR Model}

Our base approach of the exchange rate pass-through analysis follows the work of McCarthy (1999) and Ito \& Sato (2006). We will estimate a structural VAR (SVAR) as follow ${ }^{7}$ :

$y_{t}=\left(\mathrm{dlNEER}_{t}, \text { dlIMP }_{t}, d l P P I_{t} d l C P I_{t}\right)^{\prime}$

Under Choleski's decomposition of the SVAR model, we have:

$\left[\begin{array}{c}\mathrm{u}_{\mathrm{t}}{ }^{\mathrm{NEER}} \\ \mathrm{u}_{\mathrm{t}}^{\mathrm{IMP}} \\ \mathrm{u}_{\mathrm{t}}^{\mathrm{PPI}} \\ \mathrm{u}_{\mathrm{t}}{ }^{\mathrm{CPI}}\end{array}\right]=\left[\begin{array}{llll}\mathrm{c}_{11} & 0 & 0 & 0 \\ \mathrm{c}_{21} & \mathrm{c}_{22} & 0 & 0 \\ \mathrm{c}_{31} & \mathrm{c}_{32} & \mathrm{c}_{33} & 0 \\ \mathrm{c}_{41} & \mathrm{c}_{42} & \mathrm{c}_{43} & \mathrm{c}_{44} \\ & & & \end{array}\right]\left[\begin{array}{l}\mathrm{e}_{\mathrm{t}}{ }^{\mathrm{NEER}} \\ \mathrm{e}_{\mathrm{t}}^{\mathrm{IMP}} \\ \mathrm{e}_{\mathrm{t}}^{\text {PPI }} \\ \mathrm{e}_{\mathrm{t}}\end{array}\right]$

\footnotetext{
${ }^{7}$ NEER: nominal effective exchange rate, IMP = importation index price, ISPI = industrial sales price index as proxy for the production price index (PPI), CPI = consumer price index. All the variants are seasonally adjusted with the X13 program, they are in logarithm and they are stationary after the first difference ( $L$ design the $L o g$ and $D$ design the first difference). At first we used 6 variants (dloil - GAP - dlNEER - dlIMP - dlPPI - dlCPI) but after we reduced to 4 variants (dlNEER - dlIMP - dlPPI - dlCPI). The information conditions $S C$, AIC and $H Q$ give two lags $(p=2)$.The exogenous variants used are: dummies of revolution 2011, financial crisis in 2008 and Jerba attack in 2002 - MMR - exchange rate EUR/USD.
} 
With:

$e_{t}:$ is error term with variance-covariance matrix $E_{e_{t} e^{\prime} t^{\prime}}=\psi$

$u_{t}:$ Represents the structural shocks of the system equation

The model shows that there is a transmission of exchange rate shocks on the price chain: first a direct impact on import prices (expressed in domestic currency), the second impact on producer prices and these ultimately affect consumer prices.

Our study examines the impact of exchange rate on prices in Tunisia via an aggregated and disaggregated analysis of exchange rate pass-through. However, to our knowledge, our study is the first to address a disaggregated estimation of exchange rate pass-through, hopefully providing a formal proof on the modeling approach that could the preferable tool to examine the effect of an exchange rate's shock in Tunisia. ${ }^{8}$ In fact, Sanhedji et al. (2007) tried to break down CPI into 43 subgroups to conduct a disaggregated analysis of prices.

Nevertheless, the pass-through is calculated for the overall price index according to Panel data. As for our study, we will try to calculate a disaggregated pass-through. To that end, firstly, we tried to decompose the consumer price index into 3 subgroup-price indices (see Table 2): fresh food price index (Fresh_Food CPI), administrated price index (adm_CPI), core price index (core_CPI). To estimate a disaggregated pass-through: on energy price, on administrated food price, on core food price, on fresh food price, we have also divided the import price index (IMP) and the industrial sales price index (ISPI). ${ }^{9}$ The table below represents the recommended decomposition of the CPI in this study:

Table 2. Decomposition of CPI in Tunisia with weighting

\begin{tabular}{|c|c|c|c|c|c|}
\hline \multicolumn{3}{|c|}{ Indexes } & \multicolumn{3}{|c|}{ Weighting (\%) } \\
\hline \multirow{6}{*}{ Global CPI } & \multicolumn{2}{|c|}{ Fresh_Food CPI } & \multicolumn{2}{|c|}{13.94} & \multirow{6}{*}{100} \\
\hline & \multirow{3}{*}{ adm_CPI } & adm_food_cpi & 5.926 & \multirow{3}{*}{26.273} & \\
\hline & & energy_cpi & 6.594 & & \\
\hline & & other_adm_cpi & 13.753 & & \\
\hline & \multirow[b]{2}{*}{ core_CPI } & core_food_cpi & 8.197 & \multirow[b]{2}{*}{59.787} & \\
\hline & & other_core_cpi & 51.590 & & \\
\hline
\end{tabular}

Source: $C B T$

${ }^{8}$ Exchange rate passthrough is obtained by price cumulative pulse responses to an innovation unit of exchange rate in the SVAR.

${ }^{9}$ Import prices and ISPI are also broken down into food prices, energy prices and other import prices or other ISPI price. 
We notice the higher share of administrated prices in the consumer price's basket, which is currently around $27 \%$ despite the liberalization process engaged by the government (study of the CBT, and the annual rapport of CBT 2014).

\subsection{Data}

Our empirical approach is based on two estimating modes: *Estimation on monthly series from 2000M1 to 2015 M12 and quarterly series from 2000Q1 to 2015Q4. *then, an Out-sample Estimation divides the global sample in two: before the revolution till 2010 and after the revolution from 2011. The data resources are the international financial statistics of the IMF and the Central Bank of Tunisia.

\section{Results and discussion}

This section presents the empirical results of the SVAR model and a comparative analysis of the pass-through before and after the revolution date (2011). ${ }^{10}$

Table 3: ERPT on monthly data: 2000M1 to $2015 \mathrm{M} 12$

\begin{tabular}{|l|l|l|l|}
\hline & $\mathbf{2 0 0 0 - 2 0 1 5}$ & $\mathbf{2 0 0 0 - 2 0 1 0}$ & $\mathbf{2 0 1 1 - 2 0 1 5}$ \\
\hline IMP Price & $63.5 \%$ & $75 \%$ & $82 \%$ \\
\hline ISPI & $32 \%$ & $52 \%$ & $60 \%$ \\
\hline global CPI & $8 \%$ & $10 \%$ & $15 \%$ \\
\hline \multicolumn{5}{|l|}{} \\
\hline Core CPI & $\mathbf{2 0 0 0 - 2 0 1 5}$ & $\mathbf{2 0 0 0 - 2 0 1 0}$ & $\mathbf{2 0 1 1 - 2 0 1 5}$ \\
\hline CPI administrated & $5 \%$ & $10 \%$ & $4 \%$ \\
\hline Fresh Food CPI & $5 \%$ & $8 \%$ & $10 \%$ \\
\hline
\end{tabular}

\begin{tabular}{|l|l|l|l|}
\hline & $\mathbf{2 0 0 0 - 2 0 1 5}$ & $\mathbf{2 0 0 0 - 2 0 1 0}$ & $\mathbf{2 0 1 1 - 2 0 1 5}$ \\
\hline Adm_food CPI & $14 \%$ & $2 \%$ & $6 \%$ \\
\hline CPI core food & $6 \%$ & $10 \%$ & $8 \%$ \\
\hline IPC Energy & $4 \%$ & $3 \%$ & $7 \%$ \\
\hline CPI other core & - & $4 \%$ & $3 \%$ \\
\hline CPI other adm & $3 \%$ & $2 \%$ & $6 \%$ \\
\hline
\end{tabular}

Table 4: ERPT on quarterly data: $2000 Q 1$ to $2015 Q 4$

\begin{tabular}{|l|l|l|l|}
\hline & $\mathbf{2 0 0 0 - 2 0 1 5}$ & $\mathbf{2 0 0 0 - 2 0 1 0}$ & $\mathbf{2 0 1 1 - 2 0 1 5}$ \\
\hline IMP Price & $60 \%$ & $55 \%$ & $70 \%$ \\
\hline ISPI & $21 \%$ & $20 \%$ & $35 \%$ \\
\hline global CPI & $10 \%$ & $10 \%$ & $20 \%$ \\
\hline \multicolumn{5}{|l|}{} \\
\hline Core CPI & $\mathbf{2 0 0 0 - 2 0 1 5}$ & $\mathbf{2 0 0 0 - 2 0 1 0}$ & $\mathbf{2 0 1 1 - 2 0 1 5}$ \\
\hline
\end{tabular}

\footnotetext{
${ }^{10}$ We have used the bilateral exchange rate: Tnd-USD for administered food CPI - core food CPI - Energy CPI
} 


\begin{tabular}{|l|l|l|l|}
\hline CPI administrated & - & $20 \%$ & $15 \%$ \\
\hline Fresh Food CPI & $30 \%$ & $30 \%$ & $45 \%$ \\
\hline
\end{tabular}

\begin{tabular}{|l|l|l|l|}
\hline & $\mathbf{2 0 0 0 - 2 0 1 5}$ & $\mathbf{2 0 0 0 - 2 0 1 0}$ & $\mathbf{2 0 1 1 - 2 0 1 5}$ \\
\hline Adm_food CPI & $9 \%$ & $14 \%$ & $8 \%$ \\
\hline CPI core food & - & $5 \%$ & $11 \%$ \\
\hline IPC Energy & - & - & $13 \%$ \\
\hline CPI other core & $4 \%$ & $12 \%$ & $7 \%$ \\
\hline CPI other adm & $6 \%$ & - & $6 \%$ \\
\hline
\end{tabular}

Source: authors calculation

The first result is an empirical evidence that is largely validated by previous studies, like those of McCarthy (2000) and Hahn (2003): the pass-through is more important for import prices than for ISPI than for the CPI and there is an incomplete transmission on the two indices: IMP and ISPI. The total exchange rate pass-through is about $15 \%$ for monthly data and $20 \%$ for quarterly data after 2011 . It was around $10 \%$ before 2011 . These results are roughly like those obtained by the CBT $(2015)^{11}$. Second, the results on the disaggregated pulsed shocks show there is a pass-through on administered prices about $8 \%$ between 2000M1 and 2010M12, and $10 \%$ after 2011. Specifically, $6 \%$ for administered food prices and $7 \%$ for energy prices after 2011 for monthly data, unlike existing theory that admits an absence of a passthrough for administered prices.

Currently, the Euro stands at 2.500TND and the dollar at 2.200 TND. The same trend is observed for other currencies: Swiss franc, sterling pound, Japanese yen and Canadian dollar. This depreciation seems to be disturbing, it cannot be stopped once the Euro will reach 3 dinars next year; this fall will create an explosion for importation and domestic prices. Similarly, it will worsen deficits and increase debt. To avoid inconsistency between the monetary policy and the budget and to make sure monetary policy efficiently controls inflation, the share of administrated prices should be reduced in the CPI's basket (to negotiate with the IMF), as well as a better management of the loans, especially on energy, and to restudy the composition of importation, hence to streamline them. This brings us to the importance of a strong coordination between monetary policy and budgeting. However, the government has increased its subsidies after the revolution, which explains the decrease of the passthrough in administered prices between 2011 and 2015 to counteract the transmission effect of exchange rate on prices (see Figure 2). Indeed, there was a pass-through about 20\% between 2000Q1 to 2010Q4 and a pass-through about $15 \%$ between 2011Q1 to 2015Q4.

Overall, our results confirm the importance of a disaggregated analysis in studying exchange rate passthrough, and can help in the short and long-term decision-makers in Tunisia to adopt appropriate strategies to conduct monetary policy and to contain

${ }^{11}$ The study of CBT 2015 on transmission mechanisms. 
inflation. To avoid inconsistencies between monetary and fiscal policies and to ensure that monetary policy effectively controls inflation, a strategy of a policy mix must be well established in Tunisia.

Figure 2. The Evolution of subsidies in Tunisia 1997-2014

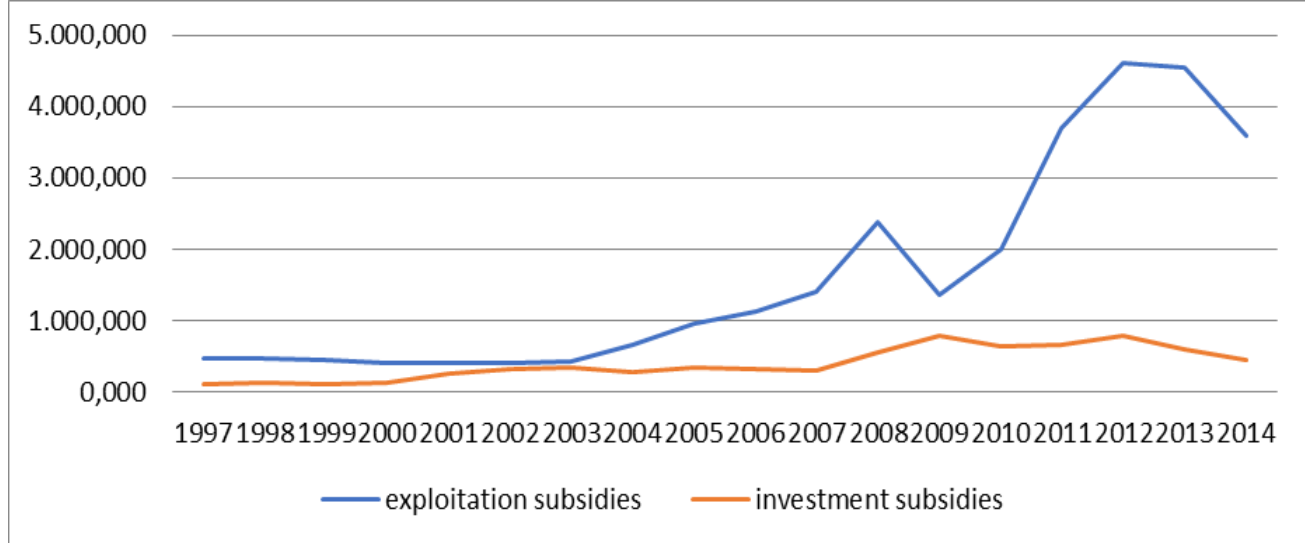

Source: authors

\section{Conclusion}

Nowadays, Tunisia (which is in a transitional phase) is maintaining a more flexible exchange rate regime by gradually liberalizing its capital accounts and following monetary policies that target price stability. Therefore, measurement and analysis of the degree of nominal exchange rate's transmission in inflation is of a great importance to conduct a proper monetary policy. Furthermore, heterogeneity in the structure of the consumer price index, as a proxy of inflation, leads us to think of a heterogeneous pass-through. Hence, for a disaggregated analysis of the passthrough, we need to breakdown the consumer price index. A contribution to the literature that has not been processed.

Examining a monthly data between 2000M01 to 2015M12 and using a VAR model, the aim of this paper is to evaluate the nominal exchange rate pass-through on the price chain: importation price, production price and consumer price according to the approach of McCarthy $(1999,2007)$ and Ito \& Sato (2006), by decomposing these indices into sub-indices. Furthermore, previous results (see table 1) show that a low degree of pass-through for Tunisia results mainly from the structure of the consumer price index (CPI), which is administrated for an important proportion of $30 \%$ (it is about $27 \%$ now). The results underline that that there is a pass-through on administered prices about $10 \%$; specifically, a degree of $6 \%$ for food administered prices and 7\% for energy prices (after 2011 for monthly data), unlike existing theory that admits an absence of a pass-through for administered prices. In general, our results confirm the importance of a degraded analysis to study exchange rate passthrough, and may help decisions-makers, in the short or the long term, to adopt the 
appropriate strategies to conduct monetary policy and to contain inflation. To avoid inconsistencies between monetary and fiscal policies and to ensure that monetary policy effectively controls inflation, a strategy of a policy mix must be well established in Tunisia.

However, since most of the analysis in this paper is based on an ad hoc estimation of exchange rate pass-through using an aggregated and disintegrated modeling, these estimations must be considered with caution. A further analysis should be considered while applying more sophisticated techniques such as the TVP VAR techniques' (time varying parameter VAR).

\section{References:}

Abida, Z., Sghaier, I.M. 2012. Transmission Des Variations Du Taux De Change Aux Prix : Évidence Empirique Pour La Tunisie Et Le Maroc. Global Journal of Management and Business Research, 12(2), 76-88.

Bailliu, J., Bouakez, H. 2004. Exchange rate pass-through in industrialized countries. Bank of Canada Review, 2, 19-28.

Bailliu, J., Fujii, E. 2004. Exchange rate pass-through and the inflation environment in industrialized countries: An Empirical Investigation. Bank of Canada, Ottawa, Working Paper, 12.

Barhoumi, K.2006. Differences in long run exchange rate pass-through into import prices in developing countries: An empirical investigation. Economic Modelling, Elsevier, vol. 23, n6, 926-951.

Barhoumi, K., Jouini, J. 2008. Revisiting the decline in the exchange rate pass-through: further evidence from developing countries. Economics Bulletin, vol. 3, n²0, 1-10.

Ben Ali, S., Jardak, T. 2014. Exchange Rate Pass-Through in Tunisia: Evidence from a Time Varying Parameter Model. Journal of Developing Areas, 48(1), 145-164.

Campa, J.M., Goldberg, L.S. 2002. Exchange Rate Pass-Through into Import Prices: A Macro or Micro Phenomenon? Federal Reserve Bank of New York, Staff Reports, No. 149.

Campa, J.M., Goldberg, L.S. 2006. Pass-Through of Exchange Rates to Consumer Prices: What Has Changed and Why? NBER Working Paper, No. 12547.

Campa, J.M., Minguez, J. 2006. Differences in exchange rate pass- through in the euro area. European Economic Review, 50, 121-145.

Chailloux, A., Durré, A., Laurens, B. 2009. Requirements for using interest rates as an operating target for monetary policy: The Case of Tunisia. IMF Working Papers, 145.

Choudhri, E.U., Hakura, D.S. 2001. Exchange Rate Pass-Through to Domestic Prices: Does the Inflationary Environment Matter? IMF Working Paper, 2001, WP/01/194.

Darvas, Z. 2001. Exchange Rate Pass-Through and Real Exchange Rate in EU Candidate Countries. Technical report, Discussion Paper Series 1/Volkswirtschaftliches Forschungszentrum der Deutschen Bundesbank.

Devereux, M.B., Yetman, J. 2002. Price-Setting and Exchange Rate Pass-Through: Theory and Evidence. Proceedings of a conference held at the Bank of Canada, Ottawa, Bank of Canada.

Delatte, A.L.,Villavicencio, A.L. 2012. Asymmetric exchange rate pass-through: Evidence from major countries. Journal of Macroeconomics, 34, 833-844. 
Edwards, S. 2006. The relationship between Exchange Rates and Inflation Targeting: Revisited. NBER Working Paper, Series ${ }^{\circ} 12163$.

El Bejaoui, H.J. 2013. Asymmetric effects of exchange rate variations: An empirical analysis for four advanced countries. International Economics, 29-46.

Faruqee, H. 2004. Exchange rate pass-through in the euro area: The role of asymmetric pricing behaviour. IMF Working Paper, $\mathrm{n}^{\circ} 14$.

Gagnon, J.E., Ihrig, J.E. 2004. Monetary Policy and Exchange Rate Pass-Through. International Journal of Finance \& Economics, 9(4), 315-338.

Goldberg, P.K., Knetter, M. 1997. Goods Prices and Exchange Rates: What Have We Learned? Journal of Economic Literature, 35(3), 1243-1272.

Goldfajn, I., Werlang, S. 2002. The pass-through from depreciation to inflation: A panel study. Central Bank of Brazil, Working Paper, $n^{\circ} 05$.

Guizani, B. 2015. Effectiveness of Monetary Policy in Economies in Democratic Transition: Evidence from Tunisia. MPRA Paper No. 63205.

Hanias, P.M., Curtis, G.P. and Thalassinos, E.J. 2007. Non-linear dynamics and chaos: The case of the price indicator at the Athens Stock Exchange. International Research Journal of Finance and Economics, 11(1), 154-163.

Haussman, R., Panniza, U., Stein, E. 2001. Why do countries float the way they float? Journal of Development Economics, 66, $\mathrm{n}^{\circ}$ 2, 387-414.

Helali, K., Klai, M., Boujelben, T. 2014. Exchange rate Pass-Through to domestic prices in Tunisia: A short and long run analysis. MPRA Paper No. 62204.

Ito, T., Sato, K. 2006. Exchange Rate Changes and Inflation in Post-Crisis Asian Economies: VAR Analysis of the Exchange Rate Pass-Through. NBER Working Paper $n^{\circ}$ 12395.

Ivohasina, F.R. 2012. Exchange Rate Pass-Through in Sub-Saharan African Economies and its Determinants. IMF Working Paper, WP/12/141.

Jebali, S., Moulahi, T., Mouha, M.S. 2009. Taux de change et Inflation: une analyse en modèle VAR du canal du taux de change : Cas de la Tunisie. Resource document. www.tn.refer.org/CEAFE/Oral_presentations/Jebali.pdf

Jimborean, R. 2013. The exchange rate pass-through in the new EU member states. Economic Systems, Elsevier, 37(2), 302-329.

Khemiri, R., Ben Ali, M.S. 2013. Exchange rate pass-through and inflation dynamics in Tunisia: A Markov-switching approach. Economics, the Open-Access, OpenAssessment E-Journal, 7, http://dx.doi.org/10.5018/economics-ejournal.ja.

Lajmi, M., El Khadhraoui, S. 2013. A model of middle term forecasting for Tunisia. Mimeo of Central Bank of Tunisia.

McCarthy, J. 1999. Pass-Through of Exchange Rates and Import Prices to Domestic Inflation in Some Industrialized Economies. BIS Working Paper, No. 79. Published in 2007 in Eastern Economic Journal, 33(4), 511.

Marrakchi- Charfi, F., Siala Guermazi, F. 2012. Transmission of Nominal Exchange Rate Variation to Domestic Prices and Monetary Policy in Tunisia. International Review of Business Research Papers, 8(5), 41-54.

Menon, J. 1995. Exchange Rate Pass-Through. Journal of Economic Surveys, 9(2), 197-231.

Miguel, A., Reginaldo, P. 2010. Is low inflation really causing the decline in exchange rate pass-through? Studies in Economics 1002, School of Economics, University of Kent.

Mihaljek, D., Klau, M. 2008. Exchange rate pass-through in emerging market Economies: what has changed and why? BIS Papers, 35, 103-130.

Miller, S.M., Choi, W.J. 2014. The Effectiveness of the Federal Funds Rate as the U.S. 
Monetary Policy Tool Before, During and After the Great Recession. European Research Studies Journal, 17(3), 37-58.

Neaime, S. 2008. Monetary policy transmission and targeting mechanisms in the MENA region. Economic Research Forum, Working Paper Series, Vol. 395.

Rapports Finaux de la BCT 2015 et 2014, et étude sur «Les mécanismes de transmission de la politique monétaire en Tunisie», Banque Centrale de Tunisie.

Sanhedji, A., Sedik, T.S., Kpodar, K. 2007. Prévisions de l'inflation et transmission des variations du taux de change aux prix à la consommation. Rapport du FM, No. $07 / 319$.

Sghaier, I.M. 2013. Taylor Rule and Monetary Policy in Tunisia. Journal of Finance and Economics, 1(4), 30-41.

Taylor, J. 2000. Low Inflation, Pass-Through and the Pricing Power of Firms. European Economic Review, 44, 1389-1408.

Thalassinos, I.E. and Politis, D.E. 2012. The evaluation of the USD currency and the oil prices: A VAR Analysis. European Research Studies Journal, 15(2), 137-146.

Thalassinos, I.E., Pociovalisteanu, D.M. 2007. A Time Series Model for the Romanian Stock Market. European Research Studies Journal, 10(3-4), 57-72.

Thalassinos, I.E., Pintea, M., Raţiu, I.P. 2015. The Recent Financial Crisis and Its Impact on the Performance Indicators of Selected Countries during the Crisis Period: A Reply. International Journal of Economics and Business Administration, 3(1), 3-20.

Zghidi, N. 2012. The asymmetric effects of Tunisian monetary policy: a threshold vector autoregressive approach. International Journal of Economics and Business Research, 4(4), 363-373. 